FERREIRA, JCA; HERNANDES, I; BRITO, ODC; CARDOSO, MR; DIAS-ARIEIRA, CR. 2017. Dosages of bokashi in the control of Meloidogyne javanica in lettuce, in greenhouse. Horticultura Brasileira 35: 224-229. DOI - http://dx.doi.org/10.1590/S0102-053620170211

\title{
Dosages of bokashi in the control of Meloidogyne javanica in lettuce, in greenhouse
}

\author{
Júlio CA Ferreira; Isabela Hernandes; Olívia DC Brito; Michelly R Cardoso; Claudia R Dias-Arieira
}

Universidade Estadual de Maringá (UEM), Umuarama-PR, Brasil; julio.cesar.antunes@hotmail.com; miragazzi@hotmail.com; crdarieira@uem.br; isabelahernandes_@hotmail.com; olivia-diullen@hotmail.com

\begin{abstract}
Root-knot nematodes are among the major phytosanitary problems on vegetables, and the use of organic matter can be a viable method to control this parasite. Thus, in the present study we aimed to investigate in a greenhouse the use of bokashi doses (organic compound produced by fermentation of grain mixtures) in the control of Meloidogyne javanica in lettuce. Substrate infestation was carried out using tomato seedlings transplanted into pots containing $2 \mathrm{~kg}$ of autoclaved soil and inoculated with 2000 eggs and eventual second stage juveniles. After 60 days, the aerial part of the tomato plant was discarded and lettuce seedlings of cv. Vera were transplanted, adding bokashi at doses of $0,5,10$ and $20 \mathrm{~g} /$ pot. One second treatment consisted in the application only at the time of transplant and another to reapply the same dosages in surface 15 days after transplanting. Forty-five (45) days after transplanting, vegetative (dry and fresh weight of aerial part) and nematological (galls and nematodes/g of root) parameters were evaluated. Doses close to $14 \mathrm{~g} /$ pot increased the vegetative growth and doses between 13 and $14 \mathrm{~g} /$ pot controlled the nematode. The application time did not affect the most of parameters studied.
\end{abstract}

Keywords: Lactuca sativa, organic matter, root-knot nematode, management.

\section{RESUMO}

Doses de bokashi no controle de Meloidogyne javanica em alface, em casa de vegetação

Nematoides das galhas destacam-se entre os principais problemas fitossanitários em hortaliças e o uso de matéria orgânica pode ser uma alternativa viável para o controle desses parasitas. Assim, objetivou-se avaliar, em casa de vegetação, o efeito de doses de bokashi (composto orgânico produzido pela fermentação de uma mistura de grãos) e da reaplicação do composto no controle de Meloidogyne javanica em alface. A infestação do substrato foi realizada utilizando plântulas de tomateiro transplantadas para vasos contendo $2 \mathrm{~kg}$ de solo autoclavado, inoculadas com 2000 ovos e eventuais juvenis de segundo estádio. Após 60 dias, a parte aérea foi descartada e novas plântulas de alface foram transplantadas, adicionando-se bokashi nas doses de $0,5,10$ e $20 \mathrm{~g} /$ vaso, nos sulcos de plantio. Os tratamentos foram realizados em duas épocas: apenas no transplante e no transplante + reaplicação superficial após 15 dias. Após 45 dias do transplante, avaliou-se parâmetros vegetativos (massa fresca da parte aérea e da raiz e massa seca da parte aérea) e nematológicos (galhas e nematoides/g de raiz). Observou-se que, doses próximas a $14 \mathrm{~g} /$ planta aumentaram o desenvolvimento vegetativo e doses entre 13 e $14 \mathrm{~g} /$ planta controlaram o nematoide. Contudo, a época de aplicação não afetou a maioria dos parâmetros estudados.

Palavras-chave: Lactuca sativa, matéria orgânica, nematoide das galhas, manejo.

\section{Received on February 3, 2016; accepted on October 5, 2016}

L ettuce (Lactuca sativa) is one of the most widely grown leafy vegetables in Brazil. However, several phytosanitary problems can limit the productivity of this crop, including fungi, viruses, bacteria and nematodes. Root-knot nematodes, especially Meloidogyne javanica and M. incognita are among the most important parasites of lettuce (Wilcken et al., 2005), particularly because most cultivars are susceptible to them (Fiorini et al., 2007; Rodrigues et al., 2012). These species are particularly significant in regions with high temperatures (Fiorini et al., 2007) that favor reproduction and fast growth of populations, which can result in losses of up to $100 \%$ of the production, depending on the infestation and cultivar used (Charchar, 1995).

The main symptom observed on diseased plants is the presence of galls on the roots, which are shorter and with few lateral roots penetrating the soil, resulting in reduced uptake of water and nutrients from the soil. The aerial parts are affected and yellowish, stunted, smaller, lighter and withered lettuce heads may be seen in the warmest periods of the day (Pinheiro et al., 2013).
When a population of root-knot nematodes becomes established in one area, eradication is practically impossible, requiring the use of integrated pest management (IPM) measures. The use of resistant cultivars is the most desirable method for reducing these populations, especially because they do not increase production costs and pose no risks to the environment. However, it is limited by the susceptibility of most cultivars to the parasite and lack of resistant genotypes adapted to different growing regions (Fiorini et al., 2007; Dias-Arieira et al., 2012; Rodrigues 
et al., 2012). Chemical control has not been recommended, since the nematicides available in the market are highly toxic, and there are no products registered for lettuce to nematode control in Brazil (Mapa, 2016).

There are alternative methods for the management of these parasites in lettuce, including the growing of antagonistic leguminous crops (Santana et al., 2012), that, in addition to reducing nematode populations, improve the biological, physical, and chemical characteristics of soil (Chieza et al., 2013). However, in this control method, the area for crop rotation must remain temporarily unavailable for the cultivation of susceptible vegetables and, typically, lettuce producers make intensive use of small areas (Dutra et al., 2003).

In this context, the use of organic matter is preferred because of its several benefits, such as increase in the population of natural enemies (Oka, 2010) and improvements in the physical and chemical properties of soil, including base saturation, porosity and conductivity of water, resulting in improved plant growth and greater tolerance to the nematode infection (McSorley \& Gallaher, 1995; Oka, 2010).

Despite the positive results obtained for the control of nematodes in vegetables with the use of organic matter (Lopes et al., 2009; Roldi et al., 2013; Dias-Arieira et al., 2015), some promising sources, such as bokashi, have not been properly assessed, and information about doses and times of application is needed.

Roldi et al. (2013) found that bokashi (organic compound produced by fermentation of grain mixtures) had the potential to control $M$. incognita in tomato plants, significantly reducing the number of galls and eggs of the nematode and improving plant growth. Later, in the assessment of different sources of organic matter, the use of bokashi (Garden Bokashi, Korin ${ }^{\circledR}$ ) promoted the greatest reduction in $M$. incognita population in lettuce (DiasArieira et al., 2015).

The present study aimed to assess the efficiency of the use of different doses and reapplication of bokashi to the control of $M$. javanica in lettuce, in greenhouse.

\section{MATERIAL AND METHODS}

The experiment was conducted at Universidade Estadual de Maringá, Umuarama, Paraná State, Brazil

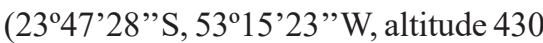
$\mathrm{m})$, in a completely randomized design, in $4 \times 2$ factorial arrangement (four doses and two times of application), with five replications. Pots with $2 \mathrm{~kg}$ of soil, mixed with sand $(2: 1)$, previously autoclaved at $120^{\circ} \mathrm{C}$ for $2 \mathrm{~h}$, were used as experimental unit. The experiments were conducted in August-December 2015, in two different environments, namely: plastic greenhouse without shading and plastic greenhouse with shading intensity of $50 \%$.

To substrate infestation, tomato seedlings cv. Santa Clara after 15 days of germination (produced in polystyrene trays, using commercial substrate Bioplant), were transplanted into pots. Five days later, the seedlings were inoculated with 2000 eggs and secondstage juveniles (J2) of M. javanica. The inoculum used was obtained from pure nematode population multiplied on tomato roots cv. Santa Clara (identificated by esterase isoenzyme) and was extracted according to the methodology proposed by Hussey \& Barker, adapted by Boneti \& Ferraz (1981), which consists in processing the infected root system in a blender with hypochlorite $0.5 \%$ and sequentially passed the processed by sieves 60 and 500 mesh, respectively. The suspension was calibrated for 500 eggs and possible $\mathrm{J} 2 / \mathrm{mL}$, and quantification was made with Peter's counting chamber, under an optical microscope. The inoculum was deposited in four equidistant holes opened in the soil around the plant stem.

After 60 days of inoculation, the aerial part of the tomato plant was discarded and the soil upturned. Then, one seedling of susceptible lettuce cv. Vera produced in tray was placed in each pot, as previously described for the tomato plant. On the day of transplant, the treatments were applied to the soil and incorporated into $5 \mathrm{~cm}$ soil depth, and consisted of doses of 0 (control); 5; 10 and $20 \mathrm{~g}$ of bokashi/pot (equivalent to $0,2.5,5.0$ and $10.0 \mathrm{~g} / \mathrm{kg}$ soil). These doses were applied at two different times: one application only at transplanting and other application at transplanting and reapplication 15 days later. The selection doses were based on search of Roldi et al. (2013). The bokashi used in the experiment was the commercial product Garden Bokashi $\left(\right.$ Korin $\left.^{\circledR}\right)$, which, according to laboratory chemical analysis, contains $71.66 \%$ of organic matter, $4.12 \%$ of total N, $2.20 \%$ of $\mathrm{CaO}, 3.40 \%$ of $\mathrm{MgO}, 3.0 \%$ of $\mathrm{K}_{2} \mathrm{O}$ and $\mathrm{P}_{2} \mathrm{O}_{5}, \mathrm{C}: \mathrm{N}$ ratio $10: 1$ and water $\mathrm{pH}$ of 5.27. In addition to $2944.4 ; 18.02$; 568.63 and $206.42 \mathrm{mg} / \mathrm{L}$ of iron, copper, manganese and zinc, respectively.

After 45 days, the lettuce plants were collected and the aerial part separated from the roots. The parameters evaluated were: fresh and dry weight of the aerial part, fresh weight of the root, galls and eggs $+\mathrm{J} 2$ number per root and eggs $+\mathrm{J} 2$ number/g root.

The fresh and dry weight of the aerial part was determined with the aid of a semi analytical balance. The dry weight was obtained after drying in forced air flow oven, at $65^{\circ} \mathrm{C}$, until constant weight. The root system was carefully washed, placed on absorbent paper to remove the excess water, and the fresh weight was then determined. Subsequently, the number of galls was determined and nematode extraction was performed according to the previously cited methodology. Finally, the number of eggs and juveniles was quantified in Peter's chamber, under an optical microscope; the total number of eggs and juveniles were divided by the root weight and the parameter eggs (eggs $+\mathrm{J} 2$ ) per gram of roots was obtained.

The data obtained were subjected to analysis of variance at $5 \%$ probability and when it was observed significance, we used quadratic regression in the dosage analysis and t-test at 5\% probability to times of application. When there was interaction between the factors, the effect of the doses was studied at each time of application. 


\section{RESULTS AND DISCUSSION}

There was no interaction between doses and time of application, regardless of the site of cultivation. The factor time of application was significant for fresh weight of root and number of galls per root system, in the experiment conducted in the plastic greenhouse without shading and for fresh weight of the aerial part for growing in plastic greenhouse with shading. For root weight, growth reduction was observed when bokashi was applied at both times, with values of 3.55 and $2.50 \mathrm{~g}$ for one and two applications, respectively. On the other hand, in the experiment conducted with shading there was increase in the dry weight of the aerial part when the product was reapplied, with means of 22.64 and $33.99 \mathrm{~g}$ for one and two applications, respectively. For galls per root system, the values were 8.56 and 5.06, for one and two applications.

Except for the fresh weight of root in the experiment with shading, all the other parameters evaluated, in both experiments, were affected by the dose of the product. Thus, the highest fresh weight of the aerial part was obtained with bokashi doses of 14.69 and 12.38 $\mathrm{g} / \mathrm{plant}$, for plants grown without and with shading, respectively (Figure 1). In turn, for the dry weight of the aerial part, the respective maximum results were 11.01 and $11.69 \mathrm{~g}$ of bokashi (Figure 2). The root weight was only affected when lettuce was grown without shading, with the highest result of $17.42 \mathrm{~g}$ (Figure 3 ). Possibly because the lettuce is a plant adapted to conditions of lesser radiant energy flow and when the plant is cultivated in an ideal brightness variation, the photosynthesis is high and the respiration is normal, resulting in increased crop yields (Bezerra et al., 2005).

In the cultivation of lettuce without shading, increase in dose from 0 to 10 $\mathrm{g}$ of bokashi increased by 4.3 times the weight of the aerial part, while in cultivation with shading this increase was 3.6 times. The beneficial effect of bokashi on lettuce growth was previously reported when $20 \mathrm{~g}$ of the product were applied per pot with $2 \mathrm{~L}$ of soil, with increases in doses from 0.66 to $26.15 \mathrm{~g}$ and 2.52 to $26.71 \mathrm{~g}$, in experiments conducted in different periods (Dias-Arieira et al., 2015). In addition to lettuce, bokashi promoted increase in the vegetative growth of tomato plant when used in the substrate composition for seedlings (Zandron et al., 2003) or in planting (Roldi et al., 2013).

Bokashi is composed of products of proven beneficial effect on plant growth, including castor bean cake (Dutra et al., 2006; Lopes et al., 2009) and bone meal
(Almeida et al., 2012), and the positive effect of the product on tomato yield was previously attributed to nutrient release in the decomposition process (Zandron et al., 2003), which can interfere with the biomass accumulation in lettuce crop (Caron et al., 2004).

From chemical analysis of bokashi it can be inferred that, in addition to providing essential nutrients, the compost has high concentration of organic matter and low $\mathrm{C}: \mathrm{N}$ ratio, indicating that the product decomposes in a short time, allowing quick release of nutrients for the plant (Villas Bôas et al., 2004); this can be especially important for short cycle plants such as lettuce. Santi et al. (2010) reported a higher fresh weight of the aerial part of different lettuce varieties with the use of manure, whose $\mathrm{C}: \mathrm{N}$ ratio was lower than that of another material investigated (sawdust). Similar results were observed by Araújo et al. (2008), who worked with three different sources of organic matter that had different $\mathrm{C}: \mathrm{N}$ ratios in lettuce.

Despite the beneficial effects of bokashi, care must been taken with the use of high doses, particularly for products with high concentration of manganese and iron. Excess iron in the solution can favor a balance shift of redox reactions towards oxidation, and the plant has morphological, biochemical and physiological responses, leading to oxidative stress (Hell \& Stephan,

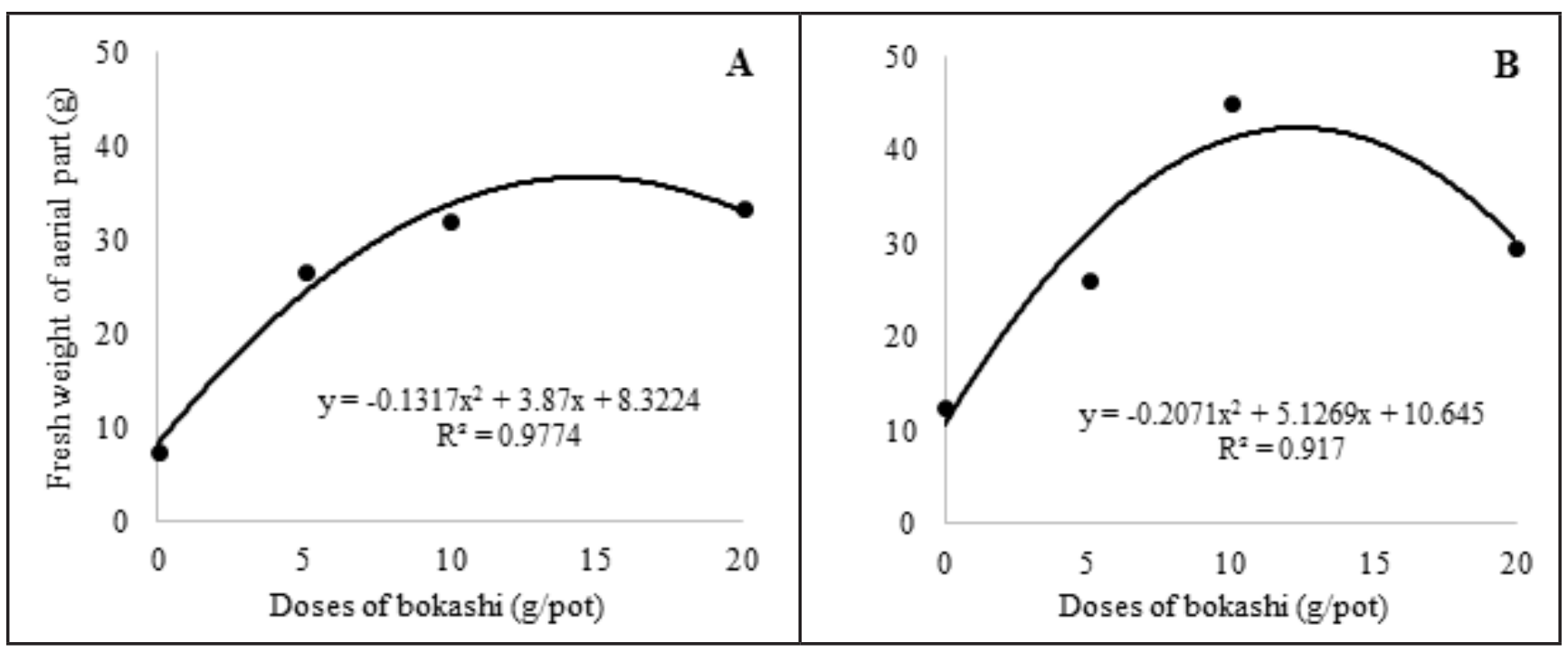

Figure 1. Fresh weight of the aerial part of lettuce infected with Meloidogyne javanica, 45 days after use of increasing doses of bokashi. $\mathrm{A}=$ greenhouse without shading; $\mathrm{B}=$ greenhouse with shading. Umuarama, UEM, 2015. 


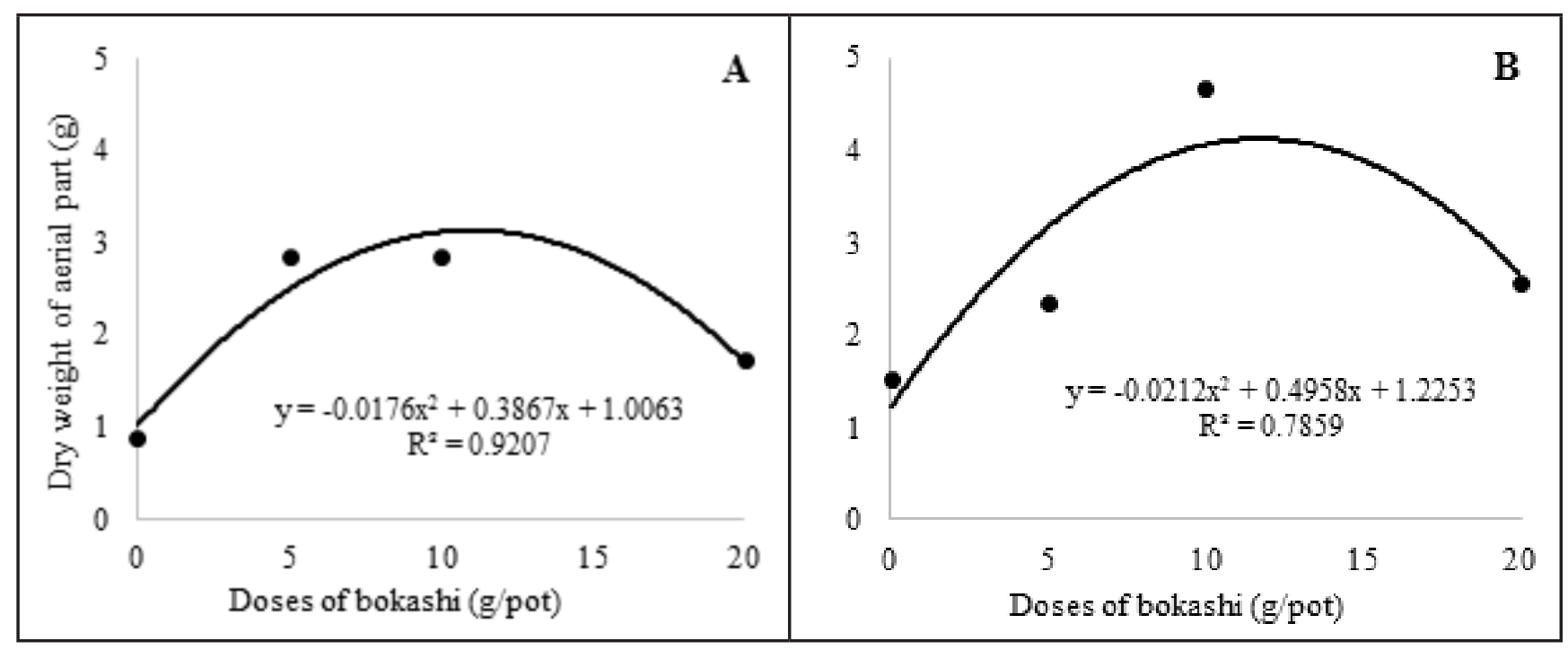

Figure 2. Dry weight of the aerial part of lettuce infected with Meloidogyne javanica, 45 days after use of increasing doses of bokashi. A= greenhouse without shading; B= greenhouse with shading. Umuarama, UEM, 2015.

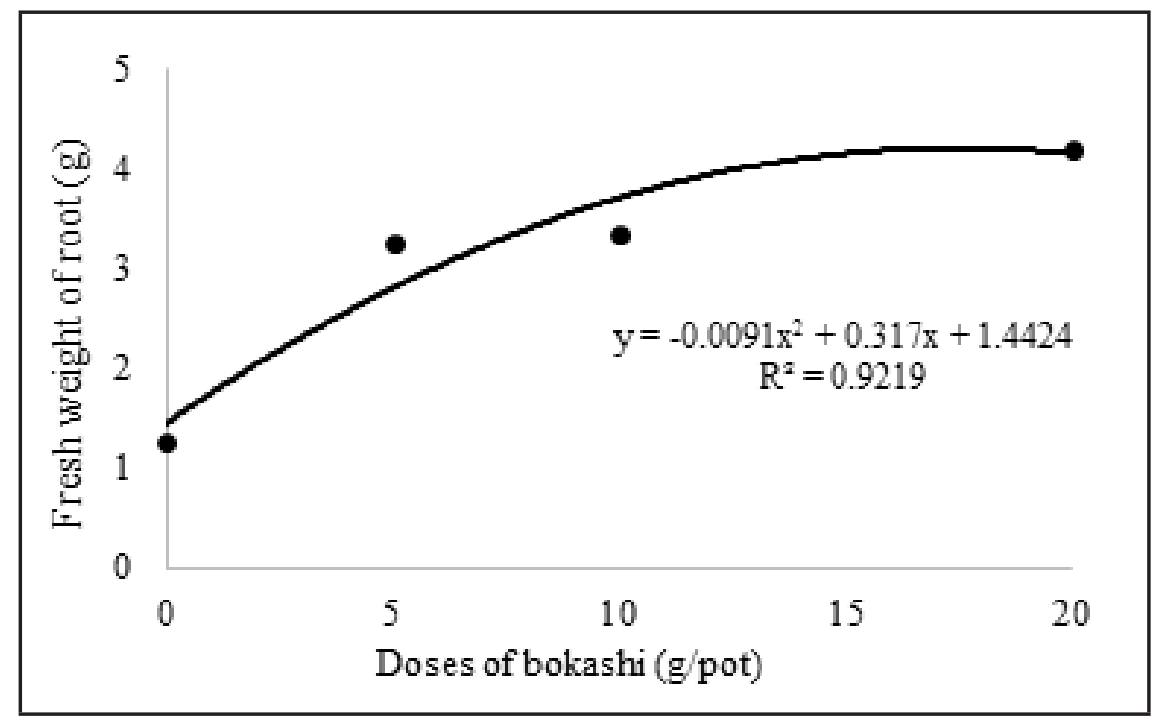

Figure 3. Fresh root weight of lettuce infected with Meloidogyne javanica, 45 days after use of increasing doses of bokashi and grown in greenhouse without shading. Umuarama, UEM, 2015.

2003). Excess manganese, in turn, accumulates in plant leaves, resulting in growth reduction of the aerial part and sometimes the root system (Marschner, 1995). Moreover, excess manganese can reduce root absorption of iron and magnesium, reduce photosynthetic activity by the reduced production of chlorophyll and auxins (Marschner, 1995; Escosteguy et al., 2006), which can explain the reduction in lettuce growth following the application of higher doses of bokashi (>15 g) observed in this study.

A greater reduction in the number of galls per root system was observed after the application of bokashi at doses 13.74 and $15.22 \mathrm{~g}$, in the experiment with and without shading, respectively (Figure 4), and regarding the number of eggs $+\mathrm{J} 2$ per root system, significant reduction occurred after application of 13.04 and $13.57 \mathrm{~g}$ of bokashi (Figure 5). Above these doses, there was increase of nematodes, possibly due to toxic effect on the plants discussed previously. Recently, it was reported that the application of $20 \mathrm{~g}$ of bokashi/pot containing $2 \mathrm{~L}$ of soil reduced the $M$. incognita reproduction in lettuce in two experiments conducted in different periods (Dias-Arieira et al., 2015). In tomato, the reproduction of $M$. incognita was also reduced with the use of $20 \mathrm{~g} / \mathrm{plant}$ : the number of eggs $+\mathrm{J} 2 / \mathrm{g}$ decreased from 5857.8 to 251.4 in treated and non-treated plants, respectively, and the presence of castor bean cake being considered one of the likely factors that act on nematodes (Roldi et al., 2013), since the efficiency of castor bean cake in the control of plant-parasitic nematodes was demonstrated in several studies involving different pathosystems (Dutra et al., 2006; Lopes et al., 2009; Roldi et al., 2013). Lopes et al. (2009) observed reductions of 18 and $48 \%$ in the number of eggs of $M$. incognita in tomato plant treated with 0.5 and $1.0 \%$ of castor bean cake, respectively, which can explain the decrease of up to $77 \%$ in the number of eggs $+\mathrm{J} 2 / \mathrm{g}$ of root in the present study after treatment with bokashi.

Another component of bokashi that may have contributed to the reduction in nematode presence is bone meal, as it has significantly reduced the presence of Meloidogyne enterolobii $(=$ M. mayaguensis) in guava (Gomes et al., 2009). Similar results in the same pathosystem, under controlled conditions, were obtained with the use of meat and bone meal at the concentration of 3\% (v:v) (Almeida et $a l ., 2012)$. In the field, the application of meat and bone meal at the dose of 50 


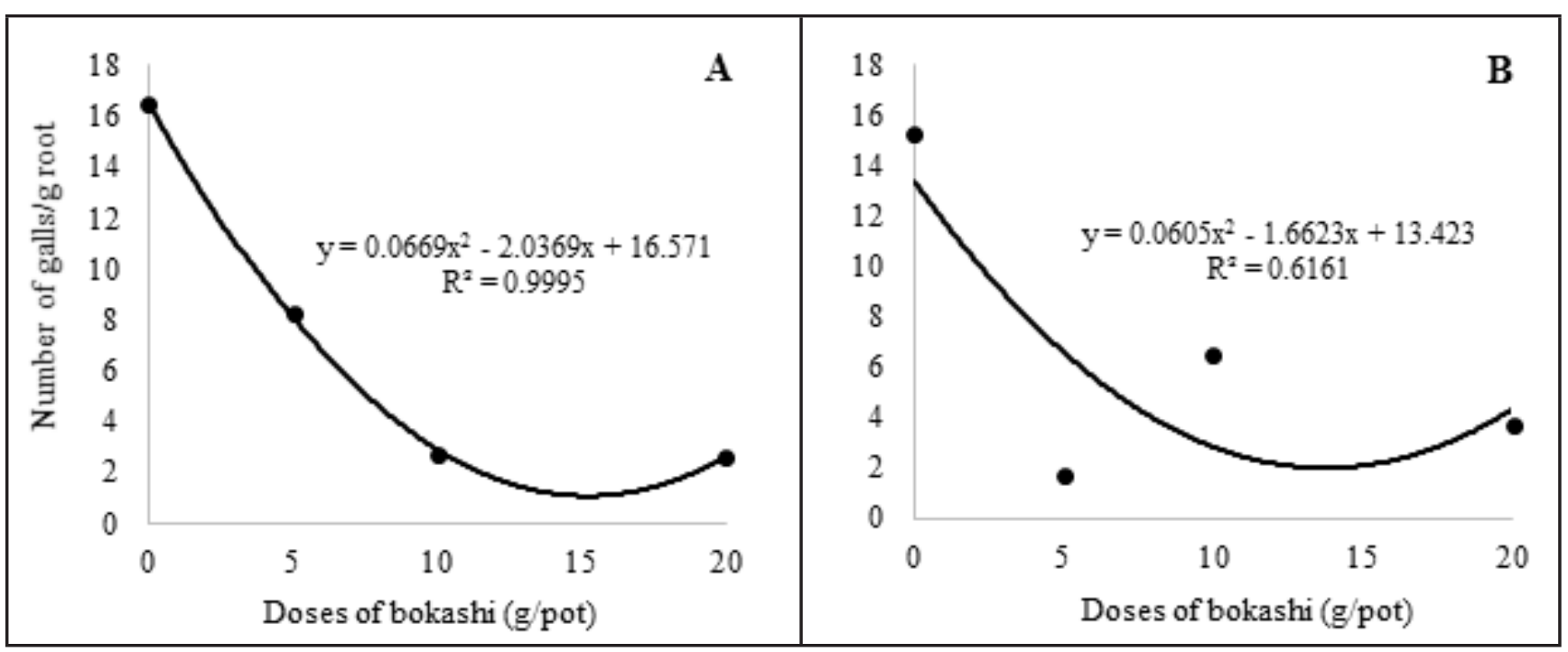

Figure 4. Number of galls of Meloidogyne javanica per gram of lettuce root 45 days after application of increasing doses of bokashi. A= greenhouse without shading; B= greenhouse with shading. Umuarama, UEM, 2015.

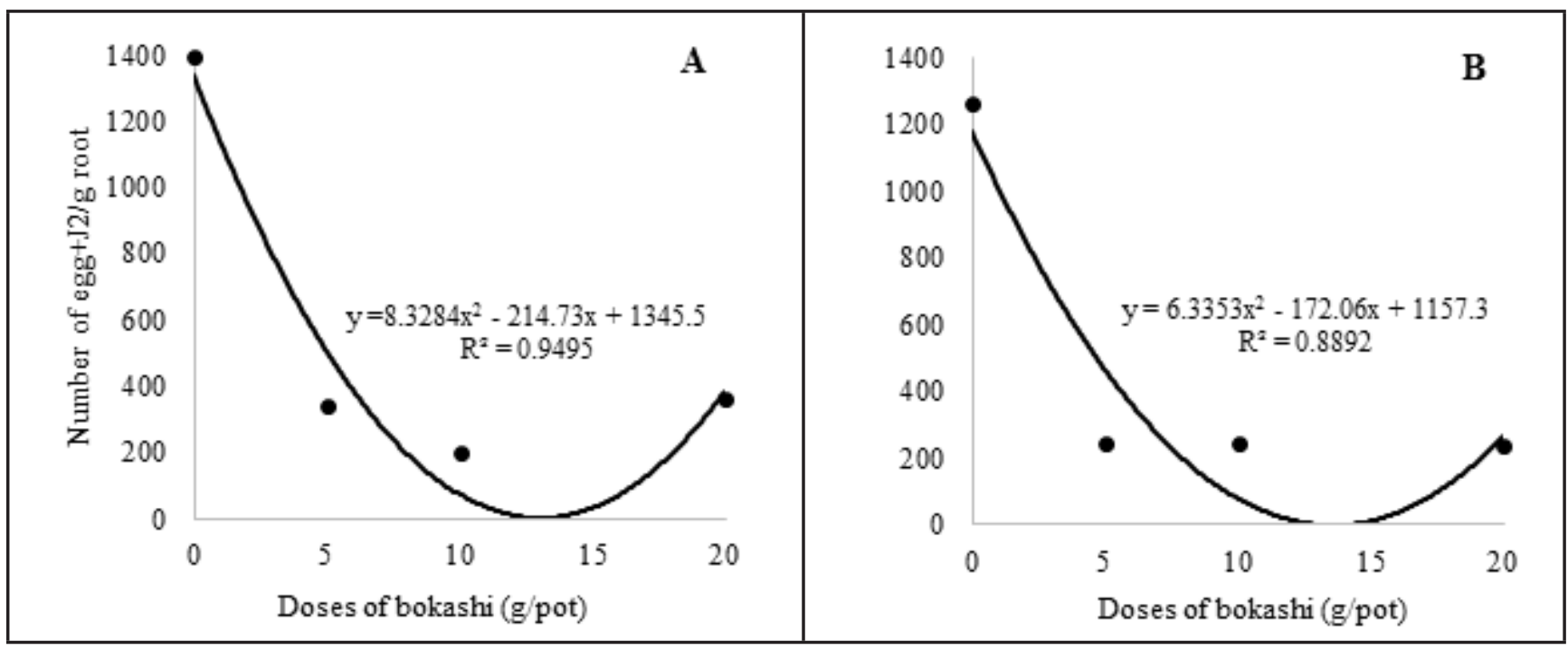

Figure 5. Number of eggs $+\mathrm{J} 2$ of Meloidogyne javanica per gram of lettuce root 45 days after application of increasing doses of bokashi. $\mathrm{A}=$ greenhouse without shading; $\mathrm{B}=$ greenhouse with shading. Umuarama, UEM, 2015.

$\mathrm{kg} /$ tree semiannualy reduced the number of plant- parasitic nematodes and the increase of bacterial-feeding nematodes (Almeida et al., 2013).

Besides the aforementioned factors, it should be stressed that the micronutrients in the product can increase plant resistance to nematode attack, acting directly on the cell structure, or indirectly in pathogen resistance induction (Barker \& Pilbeam, 2007). Also, it should be noted that the addition of compounds with high levels of organic matter can be disadvantageous for the development of nematodes (Nico et al., 2004), and that the low C:N ratio may have promoted the fast release of compounds rich in nitrogen, such as urea and ammonium nitrate during the decomposition of bokashi, which may have contributed to the results, since ammonium nitrate can promote cell plasmolysis in nematode cells (Spiegel et al., 1987). Furthermore, it is important that the organic amendments stimulate the activities of microorganisms that are antagonistic to plant-parasitic nematodes, especially fungi, bacteria and predatory nematodes (Oka, 2010).

We concluded that the use of bokashi promoted improvements in plant development and in nematode control.
The highest increase in vegetative growth was obtained with bokashi applied at a dose of approximately $14 \mathrm{~g}$ and there was increase in fresh weight of the aerial part when it carried out two applications. An application dose between 13 and $14 \mathrm{~g} /$ pot promoted decrease in $M$. javanica reproduction in lettuce.

\section{REFERENCES}

ALMEIDA, AM; SOUZA, RM; GOMES, VM; FERREIRA, TF; MUSSI-DIAS V. 2013. Field assessment of meat and bone meal for 
management of guava orchards affected by guava decline. Nematropica 43: 247-253.

ALMEIDA, AM; SOUZA, RM; GOMES, VM; MIRANDA, GB. 2012. Greenhouse and field assessment of different organic compounds against guava-parasitic Meloidogyne enterolobii. Bragantia 71: 67-74.

ARAÚJO, FF; GALVANI, PEREIRA, WC; TIRITAN, CS; SIMONETI, FOLONI, JS. 2008. Utilização de compostos orgânicos semicurados na produção da alface (Lactuca sativa). Revista Caatinga 21: 113-117.

BARKER, AV; PILBEAM, DJ. 2007. Handbook of Plant Nutrition. London: Taylor \& Francis Group. 613p.

BEZERRA NETO, F; ROCHA, RCC; NEGREIROS, MZ; ROCHA, RH; QUEIROGA, RCF. 2005. Produtividade de alface em função de condições de sombreamento e temperatura e luminosidade elevadas. Horticultura Brasileira 23: 189-192.

BONETI, JIS; FERRAZ, S. 1981. Modificação do método de Hussey e Barker para extração de ovos de Meloidogyne exigua de raízes de cafeeiro. Fitopatologia Brasileira 6: 553.

CARON, BO; POMMER, SF; SCHMIDT, D; MANFRON, PA; MEDEIROS, SLP. 2004. Crescimento da alface em diferentes substratos. Revista de Ciências Agroveterinárias 3: 97-104.

CHARCHAR, JM. 1995. Meloidogyne em hortaliças. In: CONGRESSO INTERNACIONAL DE NEMATOLOGIA TROPICAL, 27. Proceedings... Rio Quente: ONTA/SBN. p. 149-153.

CHIEZA, ED; LOVATO, T; ARAÚJO, ES; TONIN, J. 2013. Propriedades físicas do solo em área sob milho em monocultivo ou consorciado com leguminosas de verão. Revista Brasileira de Ciências do Solo 37: 1393-1401.

DIAS-ARIEIRA，CR; CUNHA，TPL; CHIAMOLERA, FM; PUERARI, HH; BIELA, F; SANTANA, SM. 2012. Reaction of vegetables and aromatic plants to Meloidogyne javanica and $M$. incognita. Horticultura Brasileira 30: 322-326.

DIAS-ARIEIRA, CR; MATTEI, D; PUERARI, HH; RIBEIRO, RCF. 2015. Use of organic amendments in the management of root-knot nematode in lettuce. Horticultura Brasileira
33: 488-492.

DUTRA, MR; CAMPOS, VP; TOYOTA, M. 2003. Manejo do solo e da irrigação para o controle de Meloidogyne javanica em alface. Nematologia Brasileira 27: 29-34.

DUTRA, MR; PAIVA, BRTL; MENDONÇA, PLP; GONZAGA, A; CAMPOS, VP; NETO, PC; FRAGA, AC. 2006. Utilização de silicato de cálcio e torta de mamona no controle do nematoide Meloidogyne exigua em cafeeiro irrigado. In: CONGRESSO BRASILEIRO DE MAMONA, 2. Anais... Aracaju: EMBRAPA, CNPA, $\mathrm{s} / \mathrm{n}$.

ESCOSTEGUY, PAV; KLEIN, VA; CERINI, JB; MACHADO, ME. 2006. Toxidez de manganês em soja. Revista Plantio Direto 9: 28-37.

FIORINI, CVA; GOMES, LAA; LIBÂNIO, RA; MALUF, WR; CAMPOS, VP; LICURSI, V; MORETTO, P; SOUZA, LA; FIORINI, IVA. 2007. Identificação de famílias F2:3 de alface homozigotas resistentes aos nematoides das galhas. Horticultura Brasileira 25: 509-513.

GOMES, VM; ALMEIDA, AM; SOUZA, RM; CORRÊA, FM. 2009. Efeito de diferentes concentrações de farinha de carne e osso incorporada ao solo sobre Meloidogyne mayaguensis, em casa-de-vegetação. Nematologia Brasileira 33: 406.

HELL, R; STEPHAN, UW. 2003. Iron uptake, trafficking and homeostasis in plants. Planta 216: 541-551.

LOPES, EA; FERRAZ, S; DHINGRA, OD; FERREIRA, PA; FREITAS, LG. 2009. Soil amendment with castor bean oilcake and jack bean seed powder to control Meloidogyne javanica on tomato roots. Nematologia Brasileira 33: 106-109.

MAPA. 2016. Ministério da agricultura, pecuária e abastecimento. Sistema de agrotóxicos fitossanitários. Available at http://www. agricultura.gov.br/servicos-e-sistemas/ sistemas/agrofit (accessed on August 18, 2016).

MARSCHNER, H. 1995. Mineral nutrition of higher plants. San Diego: Academic Press. 889p.

McSORLEY, R; GALLAHER, RN. 1995. Cultural practices improve crop tolerance to nematodes. Nematropica 25: 53-60.

NICO, AI; JIMÉNEZ-DÍAZ, RM; CASTILLO, P. 2004. Control of root-knot nematodes by composted agroindustrial wastes in potting mixtures. Crop Protection 23: 581-587.

OKA, Y. 2010. Mechanisms of nematode suppression by organic soil amendments. Applied Soil Ecology 44: 101-115.

PINHEIRO, JB; PEREIRA, RB; CARVALHO, ADF; RODRIGUES, CS; SUINAGA, FA. 2013. Manejo de nematoides na cultura da alface. Brasília: Embrapa Hortaliças, Circular Técnica. $8 \mathrm{p}$.

RODRIGUES, CS; PINHEIRO, JB; SUINAGA, FA; PEREIRA, RB; CARVALHO, ADF. 2012. Seleção preliminar de cultivares de alface para resistência ao nematoide-das-galhas. Horticultura Brasileira 30: S2048-S2054.

ROLDI, M; DIAS-ARIEIRA, CR; SEVERINO, JJ; SANTANA, SM; DADAZIO, TS; MARINI, PM; MATTEI, D. 2013. Use of organic amendment to control Meloidogyne incognita on tomatoes. Nematropica 43: 49-55.

SANTANA, SM; DIAS-ARIEIRA, CR; BIELA, F; CUNHA, TPL; CHIAMOLERA, FM; ROLDI, M; ABE, VHF. 2012. Antagonistic plants in the management of Meloidogyne incognita, in sandy soil of vegetables growing areas. Nematropica 42: 287-294.

SANTI, A; CARVALHO, MAC; CAMPOS, OR; SILVA, AF; ALMEIDA, JL; MONTEIRO, S. 2010. Ação de material orgânico sobre a produção e características comerciais de cultivares de alface. Horticultura Brasileira 28: 87-90.

SPIEGEL, Y; CHET, I; COHN, E. 1987. Use of chitin for controlling plant-parasitic nematodes. II. Mode of action. Plant Soil 98: 337-345.

VILLAS BÔAS, RL; PASSOS, JC; FERNANDES, M; BÜLL, LT; CEZAR, VRS; GOTO, R. 2004. Efeito de doses e tipos de compostos orgânicos na produção de alface em dois solos sob ambiente protegido. Horticultura Brasileira 22: 28-34.

WILCKEN, SRS; GARCIA, MJM; SILVA, N. 2005. Resistência de alface do tipo Americana a Meloidogyne incognita raça 2. Nematologia Brasileira 29: 267-271.

ZANDRON, AC; RODRIGUES, CDS ; MACHADO, CA; BRAGA, MP; CHAGAS, PRR. 2003. Influência do substrato no desenvolvimento da muda e o reflexo na produção de tomate. Horticultura Brasileira 21: 272-273. 